\title{
AS LUTAS POR DEMOCRACIA NO ANO DO CENTENÁRIO DE PAULO FREIRE - A CONCRETIZAÇÃO DO INÉDITO-VIÁVEL
}

\section{THE STRUGGLES FOR DEMOCRACY IN THE YEAR OF PAULO FREIRE'S BIRTH CENTENARY - THE ACHIEVEMENT OF THE UNTESTED FEASIBILITY}

\author{
Leandro Capella - Universidade Anhembi Morumbi-SP
}

\begin{abstract}
RESUMO
No contexto histórico pós-jornadas de junho e pós-golpe de 2016, vivemos sob a constante ameaça de forças que colocam em risco o Estado Democrático de Direito. No ano do centenário de Paulo Freire, o presente artigo objetiva denunciar essas situações-limite e defender a importância de apreendê-las como percebidos-destacados que obstaculizam a concretização do inédito-viável. Diante disso, realizou-se uma pesquisa bibliográfica orientada pelas categorias democracia e inédito-viável. Para discutir as concepções de democracia, o estudo ampara-se nas ideias de Marilena Chaui, Boaventura de Sousa Santos e Rubens Casara. As postulações acerca do inédito-viável, categoria essencial à matriz do pensamento de Paulo Freire, embasam-se em obras do autor e de alguns de seus comentadores, com destaque para os escritos de Ana Maria Araújo Freire. Nessa direção, procura-se compreender as categorias que subjazem o inédito-viável (situação-limite; percebido-destacado; ato-limite; ação editanda) e articulá-las a esse conceito. Finaliza-se apresentando alguns possíveis caminhos que possam orientar a conquista do inédito-viável aqui proposto, um mundo democrático marcado pelos valores de igualdade de poder, justiça social e paz.
\end{abstract}

Palavras-chave: Paulo Freire. Democracia. Percebido-destacado. Inédito-viável. Utopia.

\begin{abstract}
After the protests of June 2013 and the coup de e'tat of 2016, the political scenario in Brazil has been under constant threat from forces that put the Rule of Law in jeopardy. In the year of celebration of Paulo Freire's birth centenary, this article aims to denounce those limit-situations and defend the importance of apprehending them as stood out realities that hinder the realization of the untested feasibility. Thus, we carried out a bibliographical research focused on the concepts of democracy and untested feasibility. To discuss democracy, we found support in the ideas of Marilena Chaui,
\end{abstract}


Boaventura de Sousa Santos and Rubens Casara. The postulations about the untested feasibility were based on works by Paulo Freire and some of his commentators, giving special attention to the writings of Ana Maria Araújo Freire. In this direction, we seek to comprehend the categories of thinking which underlie the untested feasibility (limit-situation; stood out reality; limit-act; testing action) and link them to that concept. We conclude by presenting some possible ideas that can guide us in the achievement of the untested feasibility here proposed, a democracy marked by the values of equality of power, social justice and peace.

Keywords: Paulo Freire. Democracy. Stood out reality. Untested feasibility. Utopia.

Imagine um país que ganhou o seu nome de uma árvore: pau-brasil. Sua tinta vermelha a levou à beira da extinção. Só ficou o nome. Onde mais escravos morriam que nasciam, era mais barato importar outro da África. Onde todas as rebeliões foram brutalmente esmagadas e a república veio através de um golpe militar. Um país, que depois de 21 anos de ditadura, restabeleceu sua democracia e se tornou uma inspiração para muitas partes do mundo. Parecia que o Brasil tinha finalmente quebrado a sua maldição. Mas aqui estamos, com uma presidente destituída, um presidente preso e o país avançando rapidamente rumo ao seu passado autoritário. Hoje, enquanto sinto o chão se abrir embaixo dos meus pés, temo que a nossa democracia tenha sido apenas um sonho efêmero (DEMOCRACIA EM VERTIGEM, 2019).

\section{INTRODUÇÃO}

A história do Brasil é marcada por golpes políticos. A Proclamação da República em 1889, que levou ao fim do império, nasceu de um golpe. Em 1937, por meio de outro golpe, Getúlio Vargas impôs seu governo populista, marcado por inúmeras contradições. Em 1964, os militares destituíram o presidente João Goulart e instauraram um regime autoritário que feriu gravemente nossa infante democracia e durou mais de 20 anos. Uma ditadura militar, que alinhada ao proselitismo macartista estadunidense, torturou e matou milhares de brasileiros e brasileiras homens, mulheres e crianças. O regime militar que prendeu Paulo Freire pelo crime de alfabetizar conscientizando o povo das reais razões de seu sofrimento e que levou nosso autor homenageado a uma vida no exílio ${ }^{1}$. Que assassinou covardemente outro

${ }^{1}$ Em Pedagogia da Esperança: um reencontro com a Pedagogia do Oprimido (2016), Paulo Freire refere-se, em diversas passagens, à sua vida no exílio. O terceiro episódio (O EXÍlLIO, 2019) da série documental Paulo Freire, um homem do mundo, da Sesc TV, também retrata o tema. 
grande educador, Anísio Teixeira, e montou a cena de descoberta de seu corpo, como se sua morte não passasse de um trágico acidente² .

Dizer que vivemos em um Estado Democrático de Direito pleno é mais que uma imprecisão histórica. É a negação de que, na realidade, vivemos em um constante regime de exceção que nos permite algumas breves e esperançosas pausas que nos fazem sonhar e viver experiências genuinamente democráticas, como a Gestão de Paulo Freire na Secretaria Municipal de Educação de São Paulo3. Experiências também vividas durante os governos petistas de Luiz Inácio Lula da Silva (2003-2010) e Dilma Rousseff (2011-2016) que, mesmo com as incontáveis contradições e problemas de uma gestão alinhada a partidos da direita brasileira e aos interesses do capital financeiro, erradicaram a fome no país, instauraram políticas efetivas de redução da pobreza e possibilitaram o acesso da população mais carente a direitos que outrora se encontravam apenas declarados nos documentos oficiais.

Experiência democrática que ruiu a partir das jornadas de junho em 2013, quando "[...] um pequeno protesto contra o aumento da tarifa de ônibus acirrado pela repressão policial e com a ajuda da mídia e das redes sociais logo se transformaria em uma das maiores manifestações da história do país” (DEMOCRACIA EM VERTIGEM, 2019). Um movimento que gestou reivindicações difusas, e que, sequestrado por coletivos supostamente apartidários, serviu de berço às pulsões mobilizadoras que passariam a questionar o jogo da democracia representativa. Que deu força, cara e cor aos subterfúgios maquiavélicos que levaram a ex-presidenta Dilma Rousseff a sofrer um golpe jurídico-midiático-parlamentar em 2016 (CARDOSO JR.; REIS, 2018). Um golpe que, mais uma vez, feriu gravemente a nossa ainda-em-processo-de-recuperação democracia. A ex-

\footnotetext{
2 Em Breve história de vida e morte de Anísio Teixeira: desmontada a farsa da queda no fosso do elevador, João Augusto de Lima Rocha (2019) apresenta a tese de que a versão oficial da morte de Anísio Teixeira teria sido forjada por agentes de repressão da ditadura militar, que teriam assassinado o educador após sequestrá-lo na manhã de 11 de março de 1971, quando ele se dirigia à casa do acadêmico Aurélio Buarque de Holanda Ferreira.

3 Na obra A educação na cidade (2001), Paulo Freire relata a sua experiência à frente da Secretaria Municipal de Educação de São Paulo. Em Direitos humanos e educação libertadora: gestão democrática da educação pública na cidade de São Paulo (FREIRE, 2020), os organizadores Ana Maria Araújo Freire e Erasto Fortes Mendonça reapresentam A Educação na cidade e acrescentam outros escritos de Freire e de educadores que atuaram em sua gestão.
} 
presidenta e ex-militante Dilma Rousseff, cujo torturador teve o nome exaltado na farsa-espetáculo da votação que legitimou o golpe. Exaltado por um deputado conhecido por suas inclinações antidemocráticas, que viria a se tornar o presidente da república dois anos depois.

Chegamos a 2021, ano em que celebramos o centenário de nascimento de Paulo Freire, em meio à barbárie. Ano em que a pandemia da Covid-19 perdura sob os impulsos negacionistas do presidente da república Jair Messias Bolsonaro. Que vê sua popularidade derreter juntamente com a sua péssima gestão4. Um presidente que quanto mais acuado se sente, mais a barbárie professa. Que nega sua queda de popularidade e a justifica com teorias de conspiração infundadas. Atenta contra os poderes do jogo democrático. Questiona o sistema de voto eletrônico. Sugestiona a não realização das próximas eleições.

Dentro desse cenário de frágil democracia, indagamos o que Paulo Freire, se estivesse completando 100 anos, nos diria acerca das patologias democráticas que habitam nosso espaço-tempo. Como nosso homenageado as denunciaria? Quais temas ele realçaria? Que situações-limite ele condenaria? Quais epistemologias ele proporia para nos orientar - educadores e cidadãos progressistas - em nosso projeto de transformação de mundo, em busca do inédito-viável?

Tendo em vista que jamais teremos respostas precisas para essas perguntas, o presente artigo busca compreender a noção prevalecente de democracia no Brasil de 2021 e apresentar algumas respostas que nos guiem a estratégias de superação das situações-limite em busca de um Estado Democrático de Direito em sua plenitude, o inédito-viável que é objeto desta discussão. Discute-se o conceito de democracia nos tempos atuais e defende-se que as pulsões antidemocráticas emergentes são situações-limite que devem ser conscientemente percebidas $\mathrm{e}$ destacadas pelos coletivos progressistas engajados nas lutas para a sua superação.

Para isso, a primeira parte do artigo apresenta um breve histórico da categoria democracia com base em Chaui (2019), discute algumas de suas concepções

4 De acordo com a pesquisa do Datafolha divulgada em 8 jul. 2021, o índice de reprovação do governo de Jair Messias Bolsonaro atingiu a marca de 51\%, o maior desde que ele assumiu o governo, em 2019. Disponível em: https://www1.folha.uol.com.br/poder/2021/o7/datafolha-rejeicao-a-bolsonarosobe-a-51-novo-recorde-do-presidente.shtml. Acesso em: 20 jul. 2021. 
conforme as postulações de Santos (2016) e ampara-se no conceito de PósDemocracia sob o ponto de vista jurídico de Casara (2018). Na sequência, tendo como principal fonte de pesquisa, dentre outros comentadores, o pensamento de Paulo Freire (1987, 2001, 2016, 2020) e os escritos de Ana Maria Araújo Freire (2000, 2016, 2017), procura-se discutir o inédito-viável e suas categorias subjacentes: situação-limite; percebido-destacado; ato-limite; ação-editanda5. Essa base teórica alimenta as discussões presentes na terceira e última parte deste trabalho, que visa ensaiar alguns possíveis caminhos que nos transportem de nossa enferma democracia enquanto percebido-destacado ao (re)estabelecimento do Estado Democrático de Direito, o inédito-viável que aqui se sonha.

\section{A DEMOCRACIA, SEUS ROMPIMENTOS E SONHOS POSSÍVEIS}

O conceito de democracia surgiu na antiguidade clássica, na Grécia. A etimologia da palavra exprime os sentidos de poder do povo ou Estado do povo. Sua conotação original guarda semelhanças com o conceito de república, cujo significado é coisa pública. Se a democracia foi inventada pelos gregos, a república é criação dos romanos; e a queda de ambas ocorrera devido ao ressurgimento dos impérios: "o de Alexandre, que destruiu a democracia grega; o de Augusto, que destruiu a república romana" (CHAUI, 2019, p. 9). Conforme Chaui (2019), essa jornada autocrática fundada na união Igreja-Estado perpetuou-se durante toda a Idade Média e somente foi rompida no período da Renascença, com o surgimento das cidades republicanas italianas, com a Revolução Holandesa de 1581 e com a Revolução Inglesa de 1648. Contudo, "com o surgimento e desenvolvimento do capitalismo mercantil, as

\footnotetext{
5 Na produção do Abstract deste artigo, procurou-se respeitar fielmente a tradução de Myra Bergman Ramos para o inglês do conceito inédito-viável e de suas categorias subjacentes, conforme em Pedagogy of the Opressed (FREIRE, 2005). No entanto, constatou-se que a tradutora optou por não conceber um termo que representasse a categoria percebido-destacado na língua inglesa. Conforme é notado a seguir, o verbo to stand out (tornar-se notável, destacar-se) é utilizado para explicar o momento em que as situações-limite são apreendidas como percebidos-destacados: "Once perceived by indivual as fetters, as obstacles to their liberation, these situations stand out in relief from the background, revealing their true nature as concrete historical dimensions of a given reality" (FREIRE, 2005, p. 99). Por essa razão - e devido ao fato de que o verbo em questão carrega em si ambos os sentidos (ser percebido; destacar-se), optou-se por traduzi-lo neste trabalho como stood out reality, de modo que o particípio do verbo to stand out exerce a função de adjetivo que qualifica o substantivo reality, em tradução livre, realidade destacada.
} 
experiências republicanas são perdidas, e são restaurados a monarquia absoluta e os grandes impérios coloniais" (CHAUI, 2019, p. 9). Ainda de acordo com a autora, foi preciso aguardar a Revolução Francesa com seus ideais de igualdade e liberdade, o desenvolvimento do capitalismo industrial e a revolução industrial inglesa no século XIX para que a ideologia burguesa impulsionasse o surgimento da democracia moderna como democracia liberal.

Para compreender os sentidos de democracia a partir do século $\mathrm{XX}$, recorremos a Santos (2016, p. 133), que a define como "todo o processo de transformação de relações de poder desigual e relações de autoridade partilhada. Onde quer que haja luta contra o poder desigual, há processo de democratização". O autor traz para o centro da discussão a legitimidade de poder do povo cruelmente vilipendiada durante a Idade das Trevas e busca um ajuste histórico que retome os ideais de igualdade de representatividade e de participação e, em um sentido mais amplo, de igualdade nas relações de poder. Acerca do recorte histórico supramencionado, houve períodos em que "os debates foram relativamente plurais, e a diversidade das aspirações democráticas, intensamente vivida" (SANTOS, 2016, p. 13), com destaque para o início do século XX e o período pós-segunda guerra mundial. Especialmente em relação ao segundo, o capitalismo fez importantes concessões - visando à sua própria sobrevivência, ressalta-se - que possibilitaram políticas de bem-estar social, tais como: tributação progressiva; nacionalizações; intervenção do Estado na economia. No entanto, a partir dos anos 1980, o capitalismo financeiro retoma "a sua pulsão originária: acumulação infinita, concentração da riqueza, transformação potencial de qualquer atividade humana ou da natureza em mercadoria" (SANTOS, 2016, p. 163). E assim, a democracia liberal transformou-se em democracia neoliberal, que, por sua vez,

dá total primazia ao mercado de valores econômicos e, por isso, o mercado de valores políticos tem de funcionar como se fosse um mercado de ativos econômicos. Ou seja, mesmo no domínio das ideologias e das convicções políticas, tudo se compra e tudo se vende. Daí a corrupção endêmica no sistema político, corrupção não só funcional, como necessária. A democracia, enquanto gramática social e de acordo de convivência cidadã, desaparece para dar lugar à democracia instrumental, a democracia tolerada enquanto serve aos interesses de quem tem poder econômico e social para tanto (SANTOS, 2016, p. 22). 
Se por um lado, na democracia liberal os valores políticos são inegociáveis, eles recebem preço na democracia neoliberal - tais como os objetos do mercado de valores econômicos. Trata-se de um regime democrático de baixa intensidade em que tudo e todos são transformados em mercadoria. Na democracia instrumental neoliberal, o acesso aos direitos constitucionais estabelecidos e aos valores consensualmente chamados de democráticos está disponível à grande parcela da população somente até o ponto em que eles não se chocam com os interesses dos atores que detêm o poder de interferir na conjuntura social, política e econômica que se ocultam sob a égide de um ser místico e supostamente inatingível, um ser onipotente e onipresente chamado mercado.

1.1 Concepções de democracia (e possíveis superações)

Acerca das diversas concepções de democracia, Santos (2016, p. 20 e 126) cita como exemplos as Constituições do Equador de 2008 e da Bolívia de 2009, em que 3 dessas concepções são declaradamente articuladas: a democracia representativa; a participativa; e a comunitária. Conforme aponta o autor, o modelo democrático mais difundido, base da democracia liberal, é a democracia representativa, em que o povo concentra seu poder democrático na eleição de seus representantes. Embora Santos (2016, p. 119) postule a representatividade como um elemento essencial para a democracia, ele adverte que a democracia representativa se torna patológica quando a distância entre representantes e representados se alarga, e faz os segundos perderem a percepção de que seus interesses estejam sendo defendidos.

O autor defende como possível caminho para a superação dos limites da democracia representativa a sua articulação com a democracia participativa, cujo modelo centra-se na participação efetiva do povo nos processos de tomada de decisões, por exemplo, por meio de plebiscitos e referendos. Na história do Brasil pós-ditadura, tivemos dois exemplos de chamadas de consulta popular. O primeiro ocorreu em 1993, quando o povo foi consultado acerca de qual regime político o país deveria adotar: presidencialismo, parlamentarismo ou monarquia. O segundo foi o 
referendo de 2005, que consultou o povo sobre a proibição ou não da comercialização de armas no país. No primeiro caso, ganhou o presidencialismo; no segundo, o voto para que o comércio de armas não fosse restringido saiu vitorioso.

Santos (2016) também discute as práticas democrático-participativas em nível local, e utiliza como exemplo os orçamentos participativos municipais na cidade de Porto Alegre, no final da década de 1980.

O êxito da experiência foi surpreendente mesmo para seus protagonistas, reproduziu-se em muitas cidades do Brasil e de toda a América latina, suscitou a curiosidade dos líderes municipais de outros continentes nomeadamente da Europa -, que sob diferentes formas foram adotando a prática do orçamento participativo, e acabou por levar o Banco Mundial a chamar a atenção para as virtudes dessa forma de democracia participativa e recomendar sua adoção (SANTOS, 2016, p. 125-126).

Outra experiência que merece destaque é a Gestão de Paulo Freire à frente da Secretaria Municipal de Educação de São Paulo durante o mandato da prefeita Luiza Erundina, entre os anos de 1989 e 1992. Os objetivos que marcaram a ação da administração de Freire foram:

1) ampliar o acesso e a permanência dos setores populares - virtuais únicos usuários da educação pública; 2) democratizar o poder pedagógico e educativo para que todos, alunos, funcionários, professores, técnicos educativos, pais de família, se vinculem num planejamento autogestionado, aceitando as tensões e contradições sempre presentes em todo esforço participativo, porém buscando uma substantividade democrática; 3) incrementar a qualidade da educação, mediante a construção coletiva de um currículo interdisciplinar e a formação permanente do pessoal docente; 4) finalmente, o quarto grande objetivo da gestão - não poderia ser de outra maneira - é contribuir para eliminar o analfabetismo de jovens e adultos em São Paulo (GADOTTI; TORRES, 2001, p. 14-15, grifos nossos).

A proposta de Paulo Freire, como ele gostava de dizer, visava mudar a cara da escola (FREIRE, 2001; SAUL, 2020) de maneira profunda, não somente enfocando a boniteza estética, mas também a boniteza ética. No projeto freireano de mudança da cara da escola, além das reformas de salas, carteiras etc., também estavam implícitas mudanças no processo de formação de professores, na transformação do Currículo e na democratização da gestão das escolas, também realizada de forma participativa, por meio dos conselhos escolares. Ana Maria Saul, que trabalhou com Freire em sua gestão, relata seu entusiasmo e suas práticas 
rigorosamente democráticas: "Paulo Freire queria ouvir sempre e atentamente a posição de sua equipe sobre todas as propostas. Ouvia ponderações, recriava suas propostas, estimulava e dava espaço a novas proposições; externava preocupações, colocava parâmetros" (SAUL, 2020, p. 289).

Essa discussão reafirma a importância da participação efetiva do povo nas decisões em diferentes níveis, em suas formas de organização coletivas, para que a democracia representativa possa ser articulada a formas de democracia participativa, de modo que os limites da primeira sejam superados. No entanto, Santos (2016, p. 120) nos alerta que, assim como no caso da democracia representativa, a democracia participativa também possui seus limites, nomeados pelo autor patologia da participação, que ocorre quando os cidadãos deixam de acreditar que seu voto mudará a situação concreta vigente e, por isso, deixam de votar. Assim, aos poucos a patologia da representação transforma-se na patologia da participação, pois a mudança de representantes não muda o cenário político, tampouco o sistema político, ou seja, as eleições mudam pouco as coisas.

Santos (2016) ainda discute um terceiro tipo de democracia, a comunitária. Para isso, ele utiliza as Constituições da Bolívia e do Equador como exemplos de importantes marcos na construção de um movimento democrático contrahegemônico. No caso da Bolívia, salienta-se

a consagração de três tipos de democracia - representativa, participativa e comunitária [...]; no caso do Equador, a consagração do Sumak Kawsay (viver bem, el buen vivir em quechua) e dos direitos da natureza (pachamama) como princípios de organização econômico social (SANTOS, 2016, p. 156).

Em ambas as Cartas Magnas há o encontro de valores eurocêntricos e indígenas por meio de propostas que enfocam o pluralismo econômico, social e cultural; a questão da participação e da divisão territorial é desenhada de forma inédita no continente (SANTOS, 2016, p. 20). Na democracia comunitária, a questão da multidiversidade e do plurinacionalismo são elementos sofisticados que apresentam caminhos possíveis à construção de uma democracia contrahegemônica, "uma nova gramática que rompa com o autoritarismo, o 
patrimonialismo, o monilitismo cultural, o não reconhecimento da diferença" (SANTOS, 2016, p. 18).

Essa articulação entre democracia representativa, participativa e comunitária é tratada por Santos (2016) como um forte impulso para a construção de uma democracia de alta intensidade, pautada em valores que almejem a igualdade, a justiça social, a defesa da natureza e dos povos originários. Para isso, aponta o autor, as formas da democracia contra-hegemônica (também, democracia radical ou revolucionária) exigem uma práxis desmercantilizadora e descolonizadora, que leve à construção de epistemologias que questionem e afrontem os causadores seculares dos rompimentos democráticos: o capitalismo, o colonialismo e o patriarcalismo. Guiando-se pelas palavras-chave democratizar, desmercantilizar, descolonizar, o autor postula:

\begin{abstract}
Democratizar a própria democracia, já que a atual se deixou sequestrar por poderes antidemocráticos. [...] Desmercantilizar significa mostrar que usamos, produzimos e trocamos mercadorias, mas que não somos mercadorias nem aceitamos relacionar-nos com os outros e com a natureza como se fossem apenas mercadorias. Somos cidadãos antes de sermos empreendedores ou consumidores e, para o sermos, é imperativo que nem tudo se compre e nem tudo se venda, que haja bens públicos e bens comuns, como água, saúde, educação. Descolonizar significa erradicar das relações sociais a autorização para dominar os outros sob o pretexto de que são inferiores: porque são mulheres, porque têm uma cor de pele diferente ou porque pertencem a uma religião distinta (SANTOS, 2016, p. 180-181).
\end{abstract}

Com base nas discussões sobre as concepções de democracia e de como essas se articulam com nosso espaço-tempo, postula-se que, embora a democracia representativa seja o modelo proeminente que povoa o universo simbólico da maioria das pessoas, a democracia não pode ser reduzida a apenas uma de suas diversas formas. Para que a democracia representativa não sofra da patologia $d a$ representação e, então, possa ser superada, faz-se necessário articulá-la a outros tipos de democracia, tais quais a participativa e a comunitária. Ainda, para que a patologia da representação não se transforme em patologia da participação, é preciso que os coletivos progressistas, organizadamente resistam e lutem contra as pulsões antidemocráticas que habitam o cerne do capitalismo em sua aliança com o colonialismo e o patriarcalismo. 
Santos (2016), por meio de três palavras-chave, salienta quefazeres para a busca do inédito-viável que é objeto deste artigo: Democratizar a democracia, considerando-se que o atual modelo fora culturalmente invadido pelas pulsões antidemocráticas do capitalismo, do patriarcalismo e do colonialismo; Desmercantilizar no sentido de que ressignifiquemos nossos modos de consumir, de olhar para o outro, para a outra e para a natureza como sujeitos de direitos; Descolonizar significa que expurguemos o opressor de dentro de nós - assim como postulado na Pedagogia do Oprimido (FREIRE, 1987) -, que nos emancipemos e nos livremos das amarras coloniais e patriarcais que habitam as relações de poder, nas lutas contra todos os tipos de preconceito, na formação de novas epistemologias de ser, de poder e de conhecer que satisfaçam as necessidades nossas, como povos do Sul global, neste espaço-tempo.

\subsection{Rupturas democráticas e(m) nosso espaço-tempo}

Centrando-se em nosso recorte histórico, marcado pela violação dos direitos democráticos no Brasil, esta discussão apoia-se na concepção jurídica de Casara (2018), que traz o conceito de Estado Pós-Democrático de Direito,

um Estado que, do ponto de vista econômico, retoma com força as propostas do neoliberalismo, ao passo que, do ponto de vista político, se apresenta como um mero instrumento de manutenção da ordem, controle das populações indesejadas e ampliação das condições de acumulação do capital e geração de lucros (CASARA, 2018, p. 16-17).

Em consonância às postulações de Santos (2016), Casara (2018) enfatiza a despretensão do Estado Pós-Democrático de Direito de se satisfazer com as violações dos limites de poder, pois nutre total desinteresse em fazer valer quaisquer limites.

Um Estado que, para atender o ultraliberalismo econômico, necessita assumir a feição de um Estado Penal, de um Estado cada vez mais forte no campo do controle social e voltado à consecução dos fins desejados pelos detentores do poder econômico. Fins que levam à exclusão social de grande parcela da sociedade, ao aumento da violência - não só da violência física, que cresce de forma avassaladora, como também da violência estrutural, produzida pelo próprio funcionamento "normal" do Estado PósDemocrático -, à inviabilidade da agricultura familiar, à destruição da 
natureza e ao caos urbano, mas que necessitam do Estado para serem defendidos e, em certa medida, legitimados aos olhos de cidadãos transformados em consumidores acríticos (CASARA, 2018, p. 25).

Nasce, assim, uma nova configuração política, em que o capitalismo atua em sua forma cada vez mais distanciada do Estado de Bem-Estar Social, impondo a lógica do lucro a qualquer preço, que será garantida com o apoio das forças repressivas do Estado. Medidas que podem embelezar parâmetros macroeconômicos de interesse do capital financeiro, mas que, fatalmente, serão responsáveis pelo aumento das desigualdades sociais, pela perda de direitos historicamente conquistados, pela destruição da natureza, pela transformação de seres humanos, por um lado, em mercadoria e, por outro, em consumidores acríticos, que apenas servem à manutenção dos interesses do onipotente $\mathrm{e}$ onipresente deus-mercado.

Outro fenômeno que Casara (2018) aponta como característica do Estado Pós-Democrático de Direito é a espetacularização do judiciário e a maneira com que decisões se tornam arbitrárias para se adequarem aos interesses políticos, econômicos e midiáticos. Como exemplo, o autor menciona o julgamento da Ação Penal 470 pelo Supremo Tribunal Federal, que ficou conhecido como Mensalão.

\begin{abstract}
Deu-se, desde o início do caso do Mensalão, "o primado do enredo sobre os fatos", que caracteriza o processo penal do espetáculo. Com isso, a pretensão de reconstruir por meio de provas o que de fato aconteceu acabou substituída pela necessidade de confirmar a hipótese acusatória, já afirmada pelos meios de comunicação de massa como verdadeira e previamente aceita pela maioria dos julgadores, preocupados em dar respostas simbólicas às campanhas midiáticas contra os acusados (CASARA, 2018, p. 194).
\end{abstract}

Também, alguns processos da Operação Lava $\mathrm{Jato}^{6}$ foram tomados pela espetacularização, em que se deram

\footnotetext{
${ }^{6}$ Operação Lava Jato é o nome de uma série de investigações realizadas pela Polícia Federal a partir de 2014 no combate à corrupção e à lavagem de dinheiro. "Na época, quatro organizações criminosas que teriam a participação de agentes públicos, empresários e doleiros passaram a ser investigadas perante a Justiça Federal em Curitiba. A operação apontou irregularidades na Petrobrás, maior estatal do país, e contratos vultosos, como o da construção da usina nuclear Angra 3". Disponível em: http://www.mpf.mp.br/grandes-casos/lava-jato/entenda-o-caso. Acesso em: 20. jul. 2021.
} 
seguidas atipicidades que foram apontadas por vários juristas como violações de direitos e garantias dos investigados e dos réus, em sua grande maioria toleradas pelo Poder Judiciário. Direitos e garantias fundamentais, vistos como obstáculos aos objetivos repressivos, moralizantes e políticos da Operação Lava Jato, teriam sido afastados (CASARA, 2018, p. 200).

Dentre as atipicidades citadas, temos: violações de imparcialidade; crimes que deveriam ser julgados em outras instâncias e que foram reunidos em uma das varas federais de Curitiba; vazamento seletivo de conversas telefônicas; vedação da prova ilícita e da cadeia de custódia probatória (CASARA, 2018, p. 201).

A figura que habita o universo simbólico como herói no julgamento da Lava Jato - com grande contribuição da mídia, salienta-se - e que, no entanto, é responsável por boa parte das violações à democracia ocorridas na Operação é, indubitavelmente, o juiz Sérgio Moro. Ao conduzir os processos que levaram à condenação do ex-presidente Luiz Inácio Lula da Silva de maneira arbitrária - cujas provas foram apresentadas pelo jurista Deltan Dallagnol por meio de uma famigerada apresentação de powerpoint -, Sérgio Moro exerceu o papel de juiz acusador, com práticas que remetem à Inquisição Espanhola, e passou a julgar o processo ao seu próprio gosto e arbítrio, como bem demonstra o jurista Elmir Duclerc acerca das circunstâncias do julgamento do ex-presidente Lula:

[...] "um juiz que, dentre outras coisas, conduziu-o, coercitivamente, fora das hipóteses legais; violou, reconhecidamente, o seu sigilo telefônico; divulgou, publicamente, conteúdo sigiloso e ilegalmente obtido; exigiu seu comparecimento, ilegalmente, a todas as audiências de oitiva de testemunhas de defesa" - é "prova cabal de que a Revolução Francesa ainda não chegou ao Brasil” (DUCLERC apud CASARA, 2018, p. 204, grifos do autor).

A história recente do Brasil é marcada por um regime democrático de baixa intensidade. É um regime que privilegia o capitalismo em sua versão neoliberal e utiliza o poder do Estado para controlar as populações indesejadas - aquelas que não podem consumir e/ou serem transformados em mercadoria. Some-se à flexibilização dos valores democráticos a espetacularização do judiciário, que promove julgamentos com roteiros preestabelecidos, alheios aos elementos apresentados nos autos dos processos. Direitos e garantias fundamentais transformam-se em 
obstáculos para a confirmação de hipóteses acusatórias que estejam em consonância com os interesses do capital financeiro, das elites, da mídia e da oposição.

Assim, o Regime Pós-Democrático de Direito afirma-se como modelo de baixa intensidade, cujos valores prescritos em nossa Carta Magna - que deveriam ser protegidos pelo poder judiciário - são arbitrariamente flexibilizados de acordo com a vontade do momento, sem maior compromisso com o cumprimento integral das leis do país.

\section{AS LUTAS POR DEMOCRATIZAÇÃO - DO PERCEBIDO-DESTACADO AO INÉDITO-VIÁVEL}

O inédito-viável é uma categoria de grande encanto na matriz do pensamento de Paulo Freire. Esse encanto não vem apenas da beleza de sua imagem acústica, vem também de toda a vontade revolucionária e esperançosa do sonho possível que sua semântica carrega. Dentre os comentadores da obra de Paulo Freire, Ana Maria Araújo Freire destaca-se como uma das principais estudiosas do inédito-viável. Acerca de seu caráter morfológico e semântico, a autora explica que "O inéditoviável não é uma simples junção de letras ou expressão idiomática sem sentido. É uma palavra na acepção freireana mais rigorosa" (FREIRE, 2000, p. 15). Sua sofisticação e profundidade de sentidos tornam-se centrais na compreensão da utopia freireana, pois o inédito-viável representa seu tempo e espaço, a denúncia e o anúncio, e "carrega no seu âmago, crenças, valores, sonhos, desejos, aspirações, medos, ansiedades, vontade e possibilidade de saber, fragilidade e grandeza humanas" (FREIRE, 2000, p. 15).

O inédito-viável surge primeiramente na Pedagogia do Oprimido com base nas categorias soluções praticáveis, de André Nicolai, e consciência máxima possível, de Lucien Goldmann (FREIRE, 1987; FREIRE, 2017; PARO; VENTURA; SILVA, 2020). Em busca de referências ao inédito-viável na obra de Paulo Freire, os pesquisadores Paro, Ventura e Silva (2020, p. 4) analisaram 38 obras publicadas entre 1968 e 2009, "individualmente ou com coautores, em vida ou post mortem, escritos originalmente ou posteriormente publicados em português". De acordo com 
o estudo, foram encontradas referências em 9 dessas obras - escritas por Paulo Freire e outros 5 autores. O Quadro 1 a seguir sistematiza essas informações:

Quadro 1 - Obras de Paulo Freire com referências ao inédito-viável

\begin{tabular}{|c|c|}
\hline AUTORIA & OBRA(S) \\
\hline - Paulo Freire & $\begin{array}{l}\text { - Pedagogia do oprimido (1968); } \\
\text { - Ação cultural para a liberdade e outros escritos } \\
\text { (1975); } \\
\text { - Â sombra desta mangueira (1995). }\end{array}$ \\
\hline $\begin{array}{l}\text { - Paulo Freire; } \\
\text { - Leonardo Boff (prefácio); } \\
\text { - Ana Maria Araújo Freire (notas). }\end{array}$ & $\begin{array}{l}\text { - Pedagogia da esperança: um reencontro com a } \\
\text { pedagogia do oprimido (2016). }\end{array}$ \\
\hline $\begin{array}{l}\text { - Aldo Vannucchi (o embasamento } \\
\text { filosófico); } \\
\text { - Wlademir Santos (o aspecto } \\
\text { metodológico). }\end{array}$ & - Paulo Freire ao vivo (1983). \\
\hline - Ana Maria Araújo Freire & $\begin{array}{l}\text { - Apresentação de Pedagogia da indignação: } \\
\text { cartas pedagógicas e outros escritos (2000); } \\
\text { - Apresentação de Pedagogia da tolerância } \\
\text { (2005); } \\
\text { - Pedagogia da solidariedade (Algumas palavras } \\
\text { ou considerações em torno da Conferência de } \\
\text { Paulo Freire) (2009). }\end{array}$ \\
\hline - Ana Lúcia de Souza Freitas (prefácio) & $\begin{array}{l}\text { - Pedagogia dos sonhos possíveis: a arte de } \\
\text { tornar o possível impossível (2001). }\end{array}$ \\
\hline
\end{tabular}

Fonte: Elaboração própria, com base em Paro, Ventura e Silva (2020, p. 5-6).

Ao discutir o inédito-viável em seu artigo intitulado Utopia e Democracia: os inéditos-viáveis na educação cidadã, Ana Maria Araújo Freire o define como um "ato de fé e sonho possível no poder gerado da possibilidade que temos homens e mulheres de, em procura intencional e coletiva, fazermo-nos mais autenticamente humanos e construirmos uma sociedade mais justa, alegre e fraterna" (FREIRE, 2000, p. 21). Nessa acepção, destaca-se a conotação utópica que o inédito-viável carrega, do sonho possível que pode vir a ser materializado por meio da vontade coletiva de homens e mulheres construírem conjuntamente um mundo mais igual, justo e democrático. Ainda acerca de sua definição, nas notas de Pedagogia da Esperança: um reencontro com a Pedagogia do Oprimido (2016), a autora o coloca como 
uma coisa inédita, ainda não claramente conhecida e vivida, mas sonhada, e quando se torna um "percebido-destacado" pelos que pensam utopicamente, esses sabem, então, que o problema não é mais um sonho, que ele pode se tornar realidade.

Assim, quando os seres conscientes querem, refletem e agem para derrubar as "situações-limite" que os e as deixaram a si e quase todos e todas limitados a ser menos; o "inédito viável" não é mais ele mesmo, mas a concretização dele no que tinha antes de inviável (FREIRE, A. M. A, 2016, p. 279).

No excerto, emergem duas categorias que subjazem o conceito de inéditoviável e cuja compreensão é essencial. Na utopia freireana, as situações-limite representam os obstáculos e as barreiras que impedem homens e mulheres de concretizarem seu sonho de libertação e transformação do mundo. Essas barreiras, também chamadas de freios, não são constituídas por elementos naturais, que sempre estiveram ali. Elas são, de fato, artefatos histórico-culturais cuja existência se dá em razão da vontade e dos interesses movidos pela aliança capitalismocolonialismo-patriarcalismo.

Ana Maria Araújo Freire (2016, p. 277) destaca que, diante das situaçõeslimite, os homens e as mulheres apresentam variadas reações: "ou as percebem como um obstáculo que não podem transpor, ou como algo que não querem transpor ou ainda como algo que sabem que existe e que precisa ser rompido e então se empenham na sua superação". No último caso, a percepção da situação-limite como algo que precisa ser rompido leva homens e mulheres a agir em busca de sua superação e, para isso, exotopicamente, separam-se epistemologicamente e distanciam-se do objeto de incômodo. Compreendem-no, assim, como um problema, que, então, passa a ser visto como "algo "percebido" e "destacado" da vida cotidiana - o "percebido destacado" - que não podendo e não devendo permanecer como tal passa a ser um tema-problema que deve e precisa ser enfrentado, portanto, deve e precisa ser discutido e superado" (FREIRE, A. M. A., 2016, p. 277-278).

O percebido-destacado é o estado em que a existência da situação-limite foi percebida criticamente pelos homens e pelas mulheres e, então, destacada como um problema a ser vencido. Assim, esses coletivos passam a realizar esforços organizados visando à sua superação. A apreensão da situação-limite como um percebido-destacado deflagrará a concretização do sonho possível, o projeto de 
mundo onde queremos viver; que ainda não existe, mas poderá existir por meio de nossas lutas e resistências: nosso inédito-viável.

Na Pedagogia do Oprimido (1987), Paulo Freire postula que quando as situações-limite são apreendidas como freios, elas tornam-se percebidosdestacados. Elas revelam-se como "dimensões concretas e históricas de uma dada realidade" (FREIRE, 1987, p. 51), não mais como algo pré-dado, como o fatalismo da visão neoliberal impõe. Dimensões que, o autor coloca, "incidem sobre elas através de ações que Vieira Pinto chama de "atos-limites" - aqueles que se dirigem à superação e à negação do dado, em lugar de implicarem na sua aceitação dócil e passiva" (FREIRE, 1987, p. 51).

Freire traz o conceito de ato-limite com base no filósofo Vieira Pinto para dar nome às ações que incidem sobre as situações-limite. Conforme o autor salienta, essas ações podem estar direcionadas à superação desses freios - quando apreendidas como percebidos-destacados por cidadãos utópicos engajados no sonho possível de transformação do mundo - ou à negação deles - quando visam à consolidação da situação-limite como barreira por aqueles cujos interesses e esforços se concentram na manutenção do status quo. Em ambos os casos, os atoslimite constituem-se como ações que implicam "uma postura decidida frente ao mundo" (FREIRE, A. M. A., 2016, p. 278). Tanto os homens interessados em sua superação quanto os homens que se beneficiam da existência dos obstáculos (portanto, querem mantê-los) são sujeitos históricos cujas ações (os atos-limite) contribuem para a contínua criação e recriação do mundo.

Com o entendimento de percebidos-destacados como situações-limite cuja nossa consciência crítica permitiu desvelar, postula-se neste trabalho que os atoslimite que concretizam o inédito-viável são nomeados, na matriz freireana, açõeseditandas:

As ações para sua superação [dos percebidos destacados] podem ser, pois, diferentes dependendo do espaço e do tempo onde são praticadas, as ações editandas, que têm a possibilidade de dar concretude aos nossos anseios, necessidades e desejos, aos nossos sonhos socialmente pretendidos, engajados, quando nos acercamos do historicamente possível ou daquilo que impossível tornarmos possível, em determinado momento histórico (FREIRE, 2017, p. 224). 
Nessa acepção, os atos-limite, quando ações editandas, tornam-se possíveis vir-a-ser que marcam as transformações do mundo, a concretização do inéditoviável. Uma vez concretizado, o inédito-viável deixa de sê-lo e transforma-se em sonho realizado, objeto de nossa utopia e que dará origem a novos inéditos-viáveis. Conforme nos ensina Ana Maria Araújo Freire, essa utopia, mantendo-se no campo dos sonhos possíveis, na especificidade de nossa inconclusão humana, não tem um fim.

É sempre, pois devenir, pois alcançado o inédito-viável pelo qual sonhamos e lutamos, dele mesmo, já não mais um sonho que seria possível, mas o sonho possível realizando-se, a utopia alcançada, ela faz brotar outros tantos inéditos viáveis quantos caibam em nossos sentimentos e em nossa razão ditada pelas nossas necessidades mais autênticas. Isso diante da dinâmica que eles implicam porque sendo palavra/práxis eles estão radical e essencialmente ligados ao que há de mais ontologicamente humano em nós: a esperança do e nos movimentos de aperfeiçoamento de nós mesmos e de nosso construir social-histórico para a paz, a justiça e a democracia (FREIRE, 2017, p. 225).

A dimensão do inédito-viável explicita-se como um ato de esperança, ação e reflexão voltado às transformações do mundo que o desenham como espaço-tempo de paz, de justiça social, de democracia. Paulo Freire nos presenteou com "o inéditoviável como tática" que possibilita a concretização de "nossos anseios, necessidades e desejos, aos nossos sonhos socialmente pretendidos, engajados e possíveis [...]" (FREIRE, 2000, p. 16). Sendo assim, a realização do ser mais e da democracia devem ser ambicionados, pois correspondem aos nossos sonhos possíveis e à nossa materialidade existencial.

\section{A CONCRETIZAÇÃO DO INÉDITO VIÁVEL - CAMINHOS POSSÍVEIS}

Para finalizar este estudo, são apresentados alguns caminhos que possam nos orientar em nossas lutas e resistências voltadas à superação das situações-limite que obstaculizam a conquista do inédito-viável. Na experiência de viver o sonho possível de um Estado Democrático de Direito pleno, marcado por valores de igualdade de poder, justiça social, direitos da natureza e paz, tornamo-nos seres ineditamenteviáveis, construtores da história, “desde que, vivamos embrenhados e imbricados 
[...] nos sonhos utópicos. No construir humano, ético e político das vidas” (FREIRE, 2000, p. 20).

3.1 A epistemologia freireana é um importante ingrediente revolucionário

As ideias de Paulo Freire mantêm-se epistemologicamente vivas na atualidade e fornecem importantes subsídios para as leituras de realidade, na compreensão dos temas que emergem no recorte espaço-temporal que marca nossa existência. A teoria freireana pauta-se na denúncia das diversas situações de desumanização e no anúncio de sua superação. A análise e problematização do par dialético denúncia-anúncio trata educação e sociedade como dimensões indissociáveis nas lutas pela libertação dos homens e mulheres. Conforme Ana Maria Araújo Freire (2000, p. 18) testemunha, “[...] Paulo acreditou e colocou como ponto fundamental de sua teoria do conhecimento: a educação e a sociedade libertadora e dialógica como a utopia a ser atingida". Dessa maneira, complementa a autora, a sua própria obra é também um inédito-viável. Ela nos guia e nos orienta para agirmos em comunhão, organizarmo-nos e mobilizarmo-nos de maneira crítica, tática e consciente.

Paulo Freire falava de democracia não somente por meio de retórica ou argumentos academicistas. Seus escritos e os escritos de seus comentadores recheiam-se de relatos que evidenciam seus quefazeres democráticos. Sua gestão à frente da Secretaria Municipal de Educação de São Paulo inundava-se pelo inéditoviável de mudança da cara da escola, por uma gestão democrática que exigia a participação efetiva de todos os sujeitos da escola. Paulo Freire não apenas falou de democracia, ele mergulhou em suas águas. Seus relatos nos inspiram e alimentam nossas lutas, pois são, em sua essência, um verdadeiro ingrediente revolucionário.

3.2 As pulsões antidemocráticas são situações-limite que devem ser apreendidas como percebidos-destacados 
Ao se depararem com as diversas situações-limite que a vida em sociedade impõe, homens e mulheres podem reagir diante delas de diversos modos: podem enxergá-las como um obstáculo intransponível; podem não se sensibilizar em torno de sua superação; ou podem reunir esforços com vistas a vencê-las. Apenas no último caso, com esse freio conscientemente vislumbrado e exotopicamente escrutinado, é que a situação-limite será apreendida como percebido-destacado.

Em nossa sociedade, muitos homens e mulheres não apreendem, necessariamente, as pulsões antidemocráticas pós-jornadas de junho e pós-golpe de 2016 como problemas percebidos e destacados a serem superados. Tomemos o exemplo de coletivos saudosos dos tempos de ditadura, que vão às ruas pedir uma intervenção militar no governo. Relativizam a morte de milhares de homens, mulheres e crianças durante a ditadura e dizem que naqueles tempos a vida era melhor. Muitos desses homens e mulheres inspiram-se em um ex-deputado - e agora presidente - que homenageou um dos maiores torturadores desse triste e vergonhoso período de nossa história em plena Casa Legislativa.

Homens e mulheres que se autoproclamam cidadãos de bem e exaltam um juiz que agiu como acusador, como inquisidor. Em uma notável inversão de valores, juízes que violam as leis e líderes políticos que fazem de processos de impeachment objetos de barganha são chamados de heróis.

Julgamentos são espetacularizados e seus vereditos pouco se atêm à reconstrução dos fatos por meio de provas. O que importa é confirmar a hipótese acusatória (CASARA, 2018).

Um presidente que desafia o Supremo Tribunal Federal, que inflama seus seguidores. Que insinua que as eleições de 2022 só ocorrerão se ele for o vencedor; e que, caso perca, será fraude e, por isso, não entregará o cargo.

São inúmeras as situações-limite vividas atualmente que atentam contra o Estado Democrático de Direito. Faz-se urgente que elas sejam percebidas e destacadas como problemas a serem combatidos e vencidos.

3.3 Devemos pensar outras formas de democracia 
$\mathrm{Na}$ sociedade capitalista pós-segunda guerra mundial, a democracia representativa emergiu e tornou-se o modelo dominante. Por meio dela, os cidadãos considerados aptos a votar elegem seus representantes. A história da civilização é marcada por impérios, autocracias e regimes ditatoriais. Logo, a democracia representativa é um importante instrumento do exercício de poder pelo povo. No entanto, as pulsões do capitalismo financeiro pressionam o sistema político por meio de lobby e verbas eleitorais, dentre outros, para que seus interesses se sobreponham aos interesses da maioria. Dessa maneira, ocorre o fenômeno que Santos (2016, p. 120) nomeia patologia da representação, quando a distância entre representantes e representados se torna "ampla e disfuncional". Sendo assim, propõe-se neste artigo pensar outras formas de democracia e exercê-las em nossas lutas e resistências como ações-editandas que concretizem "nossos sonhos socialmente pretendidos" (FREIRE, 2017, p. 224).

Devemos articular à democracia representativa formas de participação popular tais como a experiência de orçamentos participativos de Porto Alegre e a Gestão Paulo Freire em São Paulo. Para que o povo tenha o direito de escolher para onde serão direcionados seus tributos, que possa fiscalizar seu uso, que seja responsável pelas decisões tomadas e, por essa razão, aja responsavelmente. Para que os coletivos sociais se engajem e participem da gestão dos espaços comunitários, da gestão escolar, da manutenção das praças, dos pavimentos etc. Que se sintam representados na figura daqueles que elegeram, e que percebam que seu voto lhes concede o poder de inedita e viavelmente mudar a cara da polis.

Com a retomada neoliberal pós-golpe de 2016 e, sobretudo, com a eleição de Jair Bolsonaro em 2018, os direitos da natureza e dos povos originários sofreram um grande ataque cujos efeitos se evidenciam por meio do aumento da área desmatada na Amazônia, da extração ilegal de madeira e das queimadas deliberadas com o objetivo de dar pasto ao gado. As vidas de ativistas ambientais e de lideranças indígenas são sistematicamente ameaçadas por madeireiros, garimpeiros, grileiros, fazendeiros, que agem sob a proteção do governo federal. Em vista dessas denúncias, devemos articular à democracia representativa formas de democracia comunitária que declarem oficialmente os direitos da natureza, que protejam nossa fauna e nossa 
flora e reafirmem os direitos dos povos originários. Formas que assumam esses povos - outrora vilipendiados pelos colonizadores europeus e agora desumanizados pelos homens brancos brasileiros - como nações dentro de uma nação. E que deem voz a todas essas nações, promovendo o protagonismo e a autonomia nas lutas pela manutenção de sua cultura e sociedade.

3.4 Democratizar, Descolonizar, Desmercantilizar são lemas a serem adotados e vividos

Precisamos democratizar a nossa democracia, invadida e tomada pelo capitalismo financeiro de mercado, em sua aliança com o patriarcalismo e o colonialismo. Faz-se urgente desenvolver formas de pensar e agir que não permitam que decisões democraticamente tomadas sejam ameaçadas pelos caprichos de uma agência de rating ou de uma baixa da cotação nas bolsas (SANTOS, 2016, p. 180). Para que, também, a aplicação e o cumprimento das leis não sejam relativizados em julgamentos midiaticamente espetacularizados.

Precisamos também desmercantilizar. Favorecer o consumo local, sustentável consciente, que respeite os direitos da natureza. Mobilizarmo-nos contra as violações às leis trabalhistas, que nos transformam cada vez em mais em objetos, em um número no crachá. Lutarmos contra a uberização do trabalho, que vende a ilusão do empreendedorismo e explora o trabalhador em jornadas diárias de 12, 16 horas. Desmercantilizar também significa não permitir que o neoliberalismo, sob a proteção dos aparelhos repressivos do Estado, massacre economicamente e fisicamente as populações consideradas indesejadas.

Descolonizar significa expurgar o colonizador de nossos corações e mentes. É não permitir a aderência do oprimido ao opressor (FREIRE, 1987). É não reproduzir práticas escravistas em nossa sociedade. É lutar contra o racismo, o sexismo, o classismo, e contra quaisquer formas de preconceito. É concretizar a vocação ontológica dos seres humanos em serem mais em uma democracia social, étnica, sexual, racial, de gênero e religiosa (FREIRE, 2000, p. 17). É desenhar epistemologias que reflitam a nossa leitura de realidade, o nosso mundo, o mundo 
do Sul global. Para que, assim, concretizemos o inédito-viável de um Brasil mais igual e justo, respeitando e considerando nossas contradições, anseios, sonhos, ambições, valores, desejos.

\section{CONCLUSÃO}

Paulo Freire, além de grande educador, foi também um grande pensador em defesa das causas dos esfarrapados do mundo. Sua teoria, partindo da dimensão educativa para a dimensão social, torna-se uma "espécie de psicanálise históricosociocultural e política" (FROMM apud FREIRE, P., 2016, p. 146) que, sempre orientada à utopia, realiza uma investigação rigorosa acerca das reais causas de desumanização das classes oprimidas com essas pessoas, e não para elas.

No ano de 2021, Paulo Freire, se estivesse vivo, completaria 100 anos. Este momento da história é fortemente marcado pela retomada de forças obscuras que ameaçam a democracia e impõem barreiras para a materialização do sonho possível de um mundo genuinamente democrático. Em razão da ameaça que essas pulsões antidemocráticas trazem, foram propostos os seguintes caminhos possíveis em direção ao inédito-viável aqui vislumbrado: o arcabouço teórico freireano como fomento às jornadas revolucionárias; a apreensão dessas pulsões antidemocráticas como percebidos-destacados; pensar em formas de democracia que transcendam a democracia representativa; apoiar-se nos lemas Democratizar, Descolonizar, Desmercantilizar.

Com a consciência de que os estudos sobre as formas contra-hegemônicas de democracia não se encerram nas epistemologias aqui discutidas e de que os caminhos propostos são apenas um pequeno punhado de ideias dentro de um universo de possibilidades, acredita-se que este trabalho pode fornecer valorosos subsídios para a construção do inédito-viável e, dessarte, poderá inspirar a concepção de outras soluções, outros inéditos-viáveis a serem conquistados por cidadãos utópicos ineditamente viáveis. 
Sabe-se, também, que o espaço-tempo em que vivemos está em constante transformação e, nesse devenir, novos desafios, novas lutas, novas situações-limite surgem a todo instante, obrigando-nos a refletir e tomar distância do problema para, então, agir com vistas à sua superação. Sigamos esperançando esperançosos em nossas lutas e lembremos que, por mais difíceis que possam ser, a concretude mora sempre nelas como possibilidade.

\section{REFERÊNCIAS}

CARDOSO JR., José Celso; REIS, Sérgio Roberto Guedes. Resistência social e contestação popular ao golpe de 2016 no Brasil: aporias a uma era de mediocridades e outros insultos. Interfaces Científicas - Direito, Aracaju, v. 6, n. 3, p. 11-26, junho 2018. Disponível em: https://periodicos.set.edu.br/direito/article/view/5864/2905. Acesso em: 19 jul. 2021.

CASARA, Rubens R. R. Estado pós-democrático: neo-obscurantismo e gestão dos indesejáveis. 3. ed. Rio de Janeiro: Civilização Brasileira, 2018.

CHAUI, Marilena. Breve história da democracia. In: Democracia em colapso? A democracia pode ser assim: histórias, formas e possibilidades (curso). São Paulo: Boitempo/Sesc, 2019. Parte 1 - Aulas, p. 9-13.

DEMOCRACIA EM VERTIGEM. Direção: Petra Costa. Busca Vida Filmes (prod.), Netflix (distr.), 2019. (121 min).

FREIRE, Ana Maria Araújo. Utopia e Democracia: os inéditos viáveis na Educação Cidadã. In: AZEVEDO, José Clóvis de; GENTILI, Pablo; KRUG, Andréa; SIMON, Cátia. (Orgs.). Utopia e democracia na Educação Cidadã. Porto Alegre: Ed. Universidade/UFGRS/Secretaria Municipal de Educação, 2000. p. 13-21.

FREIRE, Ana Maria Araújo. Notas. In: FREIRE, Paulo. Pedagogia da Esperança: um reencontro com a Pedagogia do Oprimido. 23. ed. Rio de Janeiro/São Paulo: Paz e Terra, 2016. p. 277-333.

FREIRE, Ana Maria Araújo. Inédito-viável (verbete). In: STRECK, Danilo. R.; REDIN, Euclides; ZITKOSKI, Jaime J. (Orgs). Dicionário Paulo Freire. 3. ed. Belo Horizonte: Autêntica, 2017. p. 223-226.

FREIRE, Paulo. Pedagogia do oprimido. 17. ed. Rio de Janeiro: Paz e Terra, 1987. 
FREIRE, Paulo. A educação na cidade. 5. ed. São Paulo: Cortez, 2001.

FREIRE, Paulo. Pedagogy of the opressed. 3oth anniversary edition. RAMOS, Myra Bergman (translation), MACEDO, Donaldo (introduction). New York: The Continuum International Publishing Group Inc, 2005.

FREIRE, Paulo. Pedagogia da Esperança: um reencontro com a Pedagogia do Oprimido. 23. ed. Rio de Janeiro/São Paulo: Paz e Terra, 2016.

FREIRE, Paulo. Direitos Humanos e educação libertadora: gestão democrática da educação pública na cidade de São Paulo. FREIRE, Ana Maria Araújo; MENDONÇA, Erasto Fortes (Orgs.). 2. ed. Rio de Janeiro/São Paulo: Paz e Terra, 2020.

GADOTTI, Moacir; TORRES, Carlos Alberto. Prefácio. In: FREIRE, Paulo. A educação na cidade. 5 . ed. São Paulo: Cortez, 2001. p. 11-17.

O EXÍlIO. Direção: Cristiano Burlan. In: PAULO FREIRE, UM HOMEM DO MUNDO. Bela Filmes (produção), Sesc TV (realização), 2019. (52 min.). Disponível em: https://sesctv.org.br/programas-e-series/paulofreire/?mediaId=bf784efd4a965a5a813odd4edb9d935c. Acesso em: 20 jul. 2021.

PARO, César Augusto; VENTURA, Miriam; SILVA, Neide Emy Kurokawa e. Paulo Freire e o inédito viável: esperança, utopia e transformação na saúde. Trabalho, Educação e Saúde, Rio de Janeiro, v. 18, n. 1, 2020. Disponível em: https://doi.org/10.1590/1981-7746-solo0227. Acesso em: 19 jul. 2021.

ROCHA, João Augusto de Lima. Breve história de vida e morte de Anísio Teixeira: desmontada a farsa da queda no fosso do elevador. Salvador: Edufba, 2019.

SANTOS, Boaventura de Sousa. A difícil democracia: reinventar as esquerdas. São Paulo: Boitempo, 2016.

SAUL, Ana Maria. A radicalidade da proposta de Paulo Freire à frente da Secretaria de Educação do município de São Paulo: a construção da escola pública, popular e democrática. In: FREIRE, Paulo. Direitos Humanos e educação libertadora: gestão democrática da educação pública na cidade de São Paulo. FREIRE, Ana Maria Araújo; MENDONÇA, Erasto Fortes (Orgs.). 2. ed. Rio de Janeiro/São Paulo: Paz e Terra, 2020. p. 287-306.

\section{Sobre o autor}

Leandro Capella .Doutorando em Educação: Currículo pela PUC-SP. Mestre em Linguística Aplicada e Estudos da Linguagem pela PUC-SP. Especialista na área de 
Educação. Graduado em Comércio Exterior. Pesquisador na área de Educação. Docente da Universidade Anhembi Morumbi-SP. Leciona disciplinas relacionadas a Formação Docente, Currículo, Didática e Linguística nos cursos de Pedagogia e Letras; e a disciplina de Língua Inglesa no curso de Comércio Internacional. ORCID https://orcid.org/o0oo-0002-3559-2611 E-mail: capella.leandro@gmail.com

\section{Tramitação:}

Recebido em:29/07/2021

Aprovado em: 29/10/2021 